\title{
Report of the Korean Association of External Quality Assessment Service on Serologic Tests for Syphilis (2018-2019)
}

\author{
Taeo Ma1 ${ }^{\oplus}$, Hyun-Woo Choi ${ }^{1 \oplus}$, Rihwa Choi ${ }^{\circledR}$, Sang-Gon Lee ${ }^{2 \oplus}$, and Seung-Jung Kee ${ }^{1 \oplus}$ \\ 1Department of Laboratory Medicine, Chonnam National University Hospital, Chonnam National University Medical School, \\ Gwangju; ${ }^{2}$ Department of Laboratory Medicine, Green Cross Laboratories, Yongin, Korea
}

\section{Corresponding author:}

Seung-Jung Kee

Department of Laboratory Medicine, Chonnam National University Hospital, Chonnam National University Medical School, 42 Jebong-ro, Dong-gu, Gwangju 61469, Korea

Tel +82-62-220-5343

E-mail sjkee@jnu.ac.kr
This is an Open Access article distributed under the terms of the Creative Commons Attribution Non-Commercial License (http://creativecommons.org/licenses/ by-nc/4.0) which permits unrestricted non-commercial use, distribution, and reproduction in any medium, provided the original work is properly cited.
The 2018-2019 surveys on the external quality assessment scheme for serologic tests for syphilis in Korea were conducted by the Korean Association of External Quality Assessment Service. Proficiency testing (PT) panels consisting of three pooled serum samples were shipped to 586 and 589 laboratories participating in the program in the first and second trials of 2018 and 592 and 587 laboratories in the first and second trials of 2019, respectively. The rates of returning results for nontreponemal and treponemal tests were $89.6 \%$ and $43.9 \%$ in the first trial of 2018 and $89.3 \%$ and $43.5 \%$ in the second trial of $2018 ; 90.7 \%$ and $43.2 \%$ in the first trial of 2019 and $91.5 \%$ and $43.8 \%$ in the second trial of 2019 , respectively. The most commonly used nontreponemal tests were rapid plasma reagin (RPR) card test, followed by RPR turbidimetric immunoassay, and Venereal Disease Research Laboratory tests. The most commonly used treponemal tests were Treponema pallidum particle agglutination, followed by immunochromatographic assay, chemiluminescence immunoassay, T. pallidum latex agglutination, and fluorescent treponemal antibody absorption tests. In 2018-2019, the overall accuracy rates of nontreponemal and treponemal tests were $99.0 \%-100.0 \%$, significantly higher than the $92.5 \%-100.0 \%$ in 2017 . In 2017 , standard materials were made by pooling samples obtained from many patients, whereas in 2018-2019 they were made by pooling samples from a small number of blood donors. Based on these data, we recommend using pooled samples obtained from a smaller number of donors as standard materials for syphilis serology PT to minimize the matrix effect.

(Lab Med Qual Assur 2021;43:56-64)

Key Words External quality assessment, Proficiency testing, Serology, Syphilis

\section{서론}

대한임상검사정도관리협회는 2016년도에 새롭게 사업프 로그램을 구성하고 차세대 신빙도조사사업을 착수하였다. 그 중 감염성 세균항원항체검사 프로그램은 비트레포네마검사 (nontreponemal test)와 트레포네마검사(treponemal test)의 2항목으로 구성된 매독혈청검사에 대한 신빙도조사를 연 2회 실 시하고 있다. 2016년도 이래 2019년까지 4년간 8차에 걸쳐 감염 성 세균항원항체검사 신빙도조사가 실시되었으며, 2016년부터 2017년까지의 신빙도조사 결과에 대한 이전 보고에 이어[1], 저자 
들은 2018년부터 2019년까지의 결과를 종합적으로 분석하여 보 고하고자 한다.

\section{재료 및 방법}

\section{1. 신빙도조사 방법 및 대상기관}

2018년부터 2019년까지 총 4회에 걸쳐 감염성 세균항원항체 검사 프로그램의 비트레포네마 및 트레포네마 매독혈청검사 2항 목에 대한 신빙도조사를 실시하였다. 2018년 1차 신빙도조사에 총 3검체(IB-18-01, IB-18-02, IB-18-03)를 586기관에, 2차 신빙 도조사에 총 3검체(IB-18-04, IB-18-05, IB-18-06)를 589기관에 각각 2018년 5월과 10월에 발송하였다. 2019년 1차 신빙도조사 에 총 3검체(IB-19-01, IB-19-02, IB-19-03)를 592기관에, 2차 신 빙도조사에 총 3검체(IB-19-04, IB-19-05, IB-19-06)를 587기관 에 각각 2019년 4월과 10 월에 발송하였다. 모든 신청과 결과입력, 결과판정 등은 대한임상검사정도관리협회 홈페이지에 구축된 신 빙도조사 프로그램(http://eqas.keqas.org/)을 이용하였다.

\section{2. 관리물질 제조}

2018-2019년 감염성 세균항원항체검사 신빙도조사사업을 위 한 정도관리물질은 녹십자의료재단에서 물질 제조를 위해 대한적 십자사 혈액관리본부 생명윤리심의위원회의 승인(17-12차-정-1, 18-13차-정-4) 후 대한적십자사 혈액관리본부에서 폐기예정인 매 독검사 양성 및 음성 헌혈자 혈액을 제공받아 다음과 같이 제조하 였다. 각각의 헌혈자 혈액에 대하여 비트레포네마검사는 신속혈장 레아긴검사(rapid plasma reagin test, RPR test)를 RPR card 수기법과 혼탁도측정면역검사(turbidimetric immunoassay,
TIA) 자동화법으로, 트레포네마검사는 트레포네마라텍스응집 법(Treponema pallidum latex agglutination, TPLA), 형광 트레포네마항체흡수법(fluorescent treponemal antibody absorption, FTA-ABS)으로 매독혈청검사를 시행하였다. 추가적 으로 B형간염검사(hepatitis B virus surface antigen, $\mathrm{HBsAg}$; HBV DNA real-time polymerase chain reaction [PCR]), C형 간염검사(hepatitis C virus antibody, HCV Ab; HCV RNA realtime PCR), 후천성면역결핍증검사(human immunodeficiency virus antigen/antibody, HIV Ag/Ab; HIV RNA real-time PCR) 를 시행하였다. HBs Ag, HBV DNA real-time PCR, HCV Ab, HCV RNA real-time PCR, HIV Ag/Ab, HIV RNA real-time PCR 분석에서 음성인 혈액(2018년 24 units와 2019년 35 units)만 제조대상으로 선정하였다. 혈액을 별도의 용기에 혼합 후 교반기 를 이용하여 $150 \mathrm{rpm}, 4^{\circ} \mathrm{C}, 18$ 시간 진탕하여 균질한 검체를 제 조하였다. 균질화 과정을 거쳐 제작된 시료는 $0.22 \mathrm{M}$ Durapore Millipore를 이용하여 잔여 불순물을 여과하여 용기에 분주하였 다. 각 시료의 제조된 물질을 식별하기 위해 대한임상검사정도관 리협회로부터 받은 물질명대로 각 용기에 라벨을 부착하였으며, 운반 시 외부손상 및 파손 충격으로부터 보호하며 이물질의 혼입 과 오염을 방지하기 위해 포장작업을 실시하였다. 제조가 완료된 검체는 $-85^{\circ} \mathrm{C}$ 에서 $-70^{\circ} \mathrm{C}$ 의 초저온냉동고에 보관 후 운송일정에 맞춰 냉동상태로 대한임상검사정도관리협회로 배송, 제조물질을 인계하였으며, 인계 시 인수인계증을 통해 물질의 수량 및 상태를 재확인하였다. 제조된 정도관리물질의 평가시험에 사용된 검사, 시약, 장비는 Table 1에 기술하였다.

Table 1. Tests used for checking homogeneity, stability, and adequacy of control specimens for syphilis serology proficiency

\begin{tabular}{clll}
\hline Serologic tests for syphilis & Methods & Instruments & \multicolumn{1}{c}{ Reagents } \\
\hline Nontreponemal & RPR TIA & Cobas 8000 & Mediace RPR \\
RPR card & Manual & Asan RPR Card Test \\
& & & BD Macro-Vue RPR Card Test \\
& & ASI RPR Card Test for Syphilis \\
Treponemal & TPPA & Manual & SERODIA-TPPA \\
& TPLA & Cobas 8000 & Mediace TPLA \\
& ICA & Manual & SD Syphilis Fast 3.0 \\
& FTA-ABS & Manual & ZEUS Scientific \\
\hline
\end{tabular}

The instrument used was from the following company: Cobas 8000 (Roche Diagnostic, Basel, Switzerland). Abbreviations: RPR, rapid plasma reagin; TIA, turbidimetric immunoassay; TPPA, Treponema pallidum particle agglutination; TPLA, Treponema pallidum latex agglutination; ICA, immunochromatographic assay; FTA-ABS, fluorescent treponemal antibody absorption. *TPLA is one of the automated treponemal tests based on TIA. 


\section{3. 결과 판정 및 해석}

정성 결과는 의도된 결과와 일치하는 경우 'acceptable'하 다고 판정하였다. 이 기준에 맞지 않은 응답을 하거나 응답하 지 않은 경우 ‘unacceptable'로 판정하였다. 정성 결과가 $80 \%$ consensus(전체 기관의 결과값의 $80 \%$ 일치)에 미달하면 판 정을 보류하거나 제외하였다. Venereal Disease Research Laboratory (VDRL) 역가(titer) 결과는 최빈수 역가 \pm 1 역가 의 범위(전체 기관의 결과값의 $80 \%$ 이상 포함) 내에 있는 경우 'acceptable'하다고 판정하였다. 그 역가 범위 외에 있는 경우나 정성 결과와 일치하지 않으면 'unacceptable'로 판정하였다.

\section{결과}

\section{1. 참여기관 수 및 결과 회신율}

대한임상검사정도관리협회에서 감염성 세균항원항체검사 신 빙도조사 정도관리물질을 발송한 기관 수와 각 항목별로 최소 1 종 류 이상의 검사결과를 회신한 기관의 비율을 조사하였다. 2018년 1 차에는 총 586 기관에 신빙도조사 정도관리물질을 발송하였고, 525 기관(89.6\%)과 257기관(43.9\%)이 각각 비트레포네마검사와 트레포네마검사 결과를 회신하였다. 2018년 2차에는 총 589기관 에 신빙도조사 정도관리물질을 발송하였고, 526기관(89.3\%)과 256 기관(43.5\%)이 각각 비트레포네마검사와 트레포네마검사 결 과를 회신하였다. 2019년 1차에는 총 592기관에 신빙도조사 정 도관리물질을 발송하였고, 537 기관(90.7\%)과 256기관(43.2\%) 이 각각 비트레포네마검사와 트레포네마검사 결과를 회신하였다. 2019년 2차는 총 587기관에 신빙도조사 정도관리물질을 발송하 였고, 537기관(91.5\%)과 257기관(43.8\%)이 각각 비트레포네마 검사와 트레포네마검사 결과를 회신하였다(Table 2).

\section{2. 검사방법}

신빙도조사에 참여한 기관들의 비트레포네마검사와 트레포 네마검사 항목별 검사방법의 사용률은 공통결과보고서와 개별 결과보고서를 참조하여 회신한 모든 검사방법 총합을 기준으 로 하여 분석하였다. 2018년 1차와 2차, 2019년 1차와 2차 신빙 도조사에서 비트레포네마검사법 중 VDRL 사용률은 각각 $9.4 \%$ (54/576), 9.4\% (54/575), 9.0\% (53/587), 9.2\% (54/588)였 다. RPR card 수기법 사용률은 각각 $51.9 \%$ (299/576), 51.8\% (298/575), 51.3\% (301/587), 51.0\% (300/588)였고, RPR TIA 자동화법 사용률은 각각 $35.8 \%$ (206/576), 35.8\% (206/575), $37.1 \%$ (218/587), 37.8\% (222/588)였다. 방법을 모르는 RPR unknown 사용률도 각각 3.0\% (17/576), 3.0\% (17/575), 2.6\% (15/587), 2.0\% (12/588)였다(Table 3).

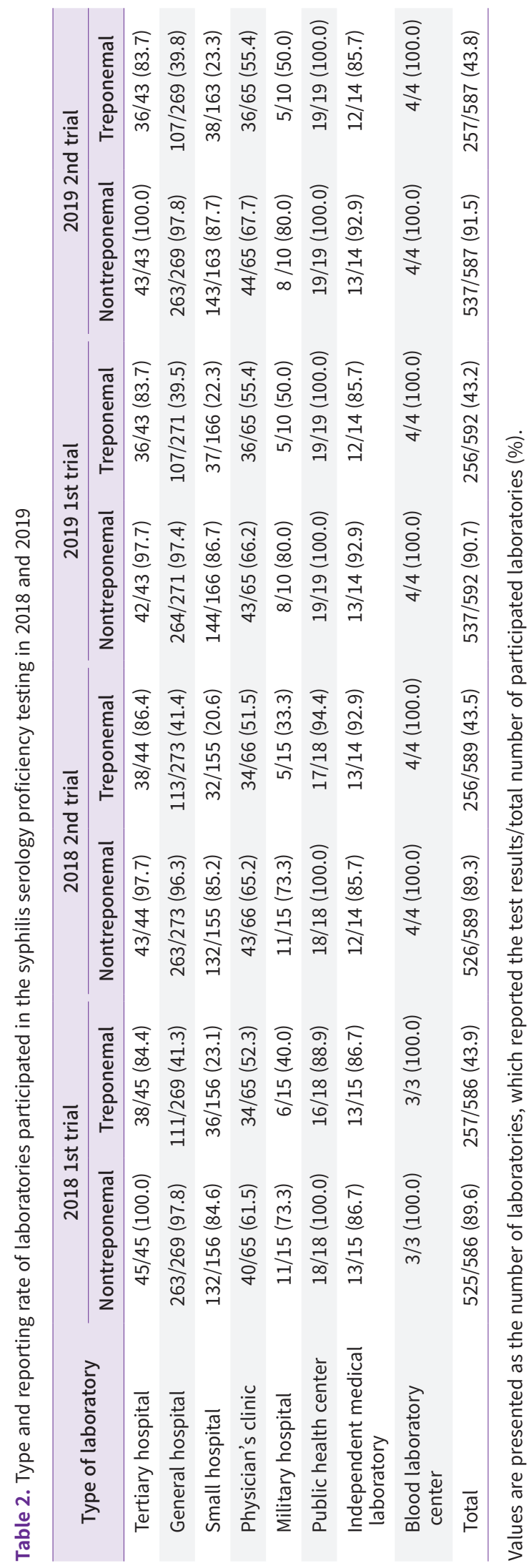


Table 3. Trend of methods used in syphilis serology proficiency testing in 2018-2019

\begin{tabular}{|c|c|c|c|c|c|}
\hline \multirow{2}{*}{$\begin{array}{l}\text { Serologic tests for } \\
\text { syphilis }\end{array}$} & \multirow{2}{*}{ Methods } & \multicolumn{2}{|c|}{2018} & \multicolumn{2}{|c|}{2019} \\
\hline & & 1st trial & 2nd trial & 1st trial & 2nd trial \\
\hline \multirow[t]{5}{*}{ Nontreponemal } & VDRL & $54(9.4)$ & $54(9.4)$ & $53(9.0)$ & $54(9.2)$ \\
\hline & RPR card & $299(51.9)$ & $298(51.8)$ & $301(51.3)$ & $300(51.0)$ \\
\hline & RPR TIA & $206(35.8)$ & $206(35.8)$ & $218(37.1)$ & $222(37.8)$ \\
\hline & RPR unknown & $17(3.0)$ & $17(3.0)$ & $15(2.6)$ & $12(2.0)$ \\
\hline & Total & $576(100.0)$ & $575(100.0)$ & $587(100.0)$ & $588(100.0)$ \\
\hline \multirow[t]{7}{*}{ Treponemal } & FTA-ABS & $12(4.3)$ & $12(4.3)$ & $12(4.3)$ & $12(4.3)$ \\
\hline & TPPA & $103(37.2)$ & $96(34.7)$ & $92(33.0)$ & $86(30.7)$ \\
\hline & TPLA $^{*}$ & $43(15.5)$ & $42(15.2)$ & $44(15.8)$ & $45(16.1)$ \\
\hline & CLIA & $42(15.2)$ & $48(17.3)$ & $48(17.2)$ & $46(16.4)$ \\
\hline & ICA & $72(26.0)$ & $73(26.4)$ & $76(27.2)$ & $85(30.4)$ \\
\hline & Unknown & $5(1.8)$ & $6(2.2)$ & $7(2.5)$ & $6(2.1)$ \\
\hline & Total & $277(100.0)$ & $277(100.0)$ & $279(100.0)$ & $280(100.0)$ \\
\hline
\end{tabular}

Values are presented as numbers (\%).

Abbreviations: VDRL, Venereal Disease Research Laboratory; RPR, rapid plasma reagin; TIA, turbidimetric immunoassay; FTA-ABS, fluorescent treponemal antibody absorption; TPPA, Treponema pallidum particle agglutination; TPLA, Treponema pallidum latex agglutination; CLIA, chemiluminescence immunoassay; ICA, immunochromatographic assay.

${ }^{*}$ TPLA is one of the automated treponemal tests based on TIA.

2018년 1차와 2차, 2019년 1차와 2차 신빙도조사에서 트 레포네마검사법 중 FTA-ABS 사용률은 각각 $4.3 \%$ (12/277), $4.3 \%$ (12/277), 4.3\% (12/279), 4.3\% (12/280)였다. 트 레포네마입자응집검사(Treponema pallidum particle agglutination, TPPA) 수기법 사용률은 각각 $37.2 \%$ (103/277), $34.7 \%$ (96/277), 33.0\% (92/279), 30.7\% (86/280)였고, TPLA TIA 자동화법 사용률은 각각 $15.5 \%$ (43/277), $15.2 \%$ (42/277), $15.8 \%$ (44/279), $16.1 \%$ (45/280)였다. 화학발광면 역검사(chemiluminescence immunoassay, CLIA) 자동화 법 사용률은 각각 $15.2 \%$ (42/277), $17.3 \%$ (48/277), $17.2 \%$ (48/279), $16.4 \%$ (46/280)였고, 면역크로마토그래피검사 (immunochromatographic assay, ICA) 사용률은 각각 $26.0 \%$ (72/277), 26.4\% (73/277), 27.2\% (76/279), 30.4\% (85/280)였 다. 방법을 모르는 트레포네마검사 사용률도 각각 $1.8 \%$ (5/277), $2.2 \%$ (6/277), 2.5\% (7/279), 2.1\% (6/280)였다(Table 3).

\section{3. 항목별 결과분석}

\section{1) 비트레포네마검사}

2018년 1차 신빙도조사사업에 2개의 음성 검체(IB-18-02, IB18-03)와 1 개의 양성 검체(IB-18-01)를, 2 차 사업에 2개의 음성 검체(IB-18-04, IB-18-06)와 1 개의 양성 검체(IB-18-05)를 각각
이용하였다. 각 검체당 회신한 모든 비트레포네마검사 결과의 총 합을 기준으로 하여 분석하였다. IB-18-01 검체에 대한 비트레포 네마검사 총 576예 중 575예가 양성, IB-18-02 검체는 총 576예 중 574예가 음성, IB-18-03 검체는 총 576예 중 574예가 음성으 로, 각각 $99.8 \%, 99.7 \%, 99.7 \%$ 의 정답률을 보였다. IB- $18-04$ 검 체에 대한 비트레포네마검사 총 575예 중 569예가 음성, IB-1805 검체는 총 575예 중 573예가 양성, IB-18-06 검체는 총 575 예 중 573 예가 음성으로, 각각 $99.0 \%, 99.7 \%, 99.7 \%$ 의 정답률 을 보였다(Table 4). 2019년 1차 신빙도조사사업에 2개의 음성 검체(IB-19-01, IB-19-02)와 1개의 양성 검체(IB-19-03)를, 2차 사업에 2개의 음성 검체(IB-19-04, IB-19-05)와 1 개의 양성 검체 (IB-19-06)를 각각 이용하였다. 각 검체당 회신한 모든 비트레포 네마검사 결과의 총합을 기준으로 하여 분석하였다. IB-19-01 검 체에 대한 비트레포네마검사 총 587예 중 587예가 음성, IB-1902 검체는 총 587예 중 586예가 음성, IB-19-03 검체는 총 587예 중 584예가 양성으로, 각각 $100 \%, 99.8 \%, 99.5 \%$ 의 정답률을 보 였다. IB-19-04 검체에 대한 비트레포네마검사 총 588예 중 585 예가 음성, IB-19-05 검체는 총 588예 중 583예가 음성, IB-1906 검체는 총 588예 중 585예가 양성으로, 각각 $99.5 \%, 99.2 \%$, $99.5 \%$ 의 정답률을 보였다(Table 5).

VDRL 역가 결과를 보았을 때 2018년 1차부터 2019년 2차까 지 양성 검체 4개(IB-18-01, IB-18-05, IB-19-03, IB-19-06)에 대 


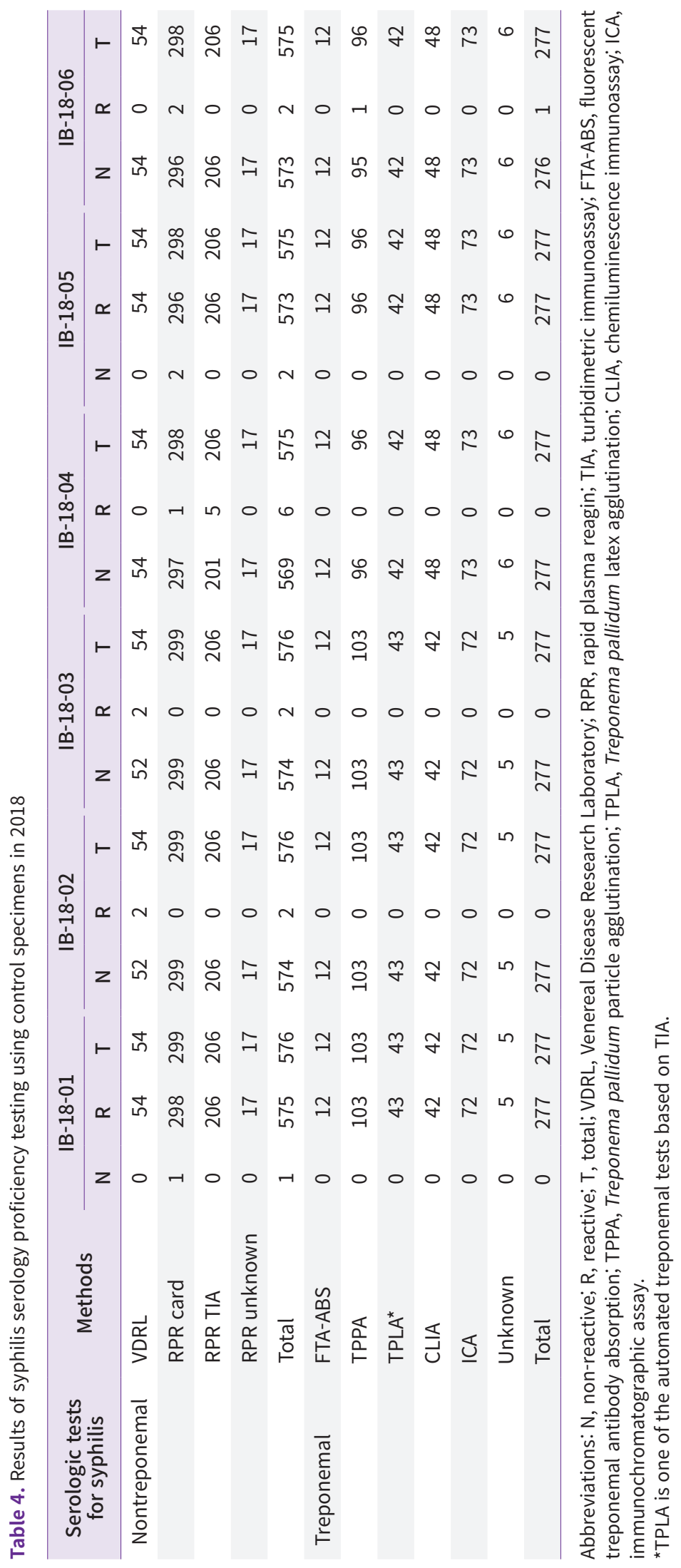




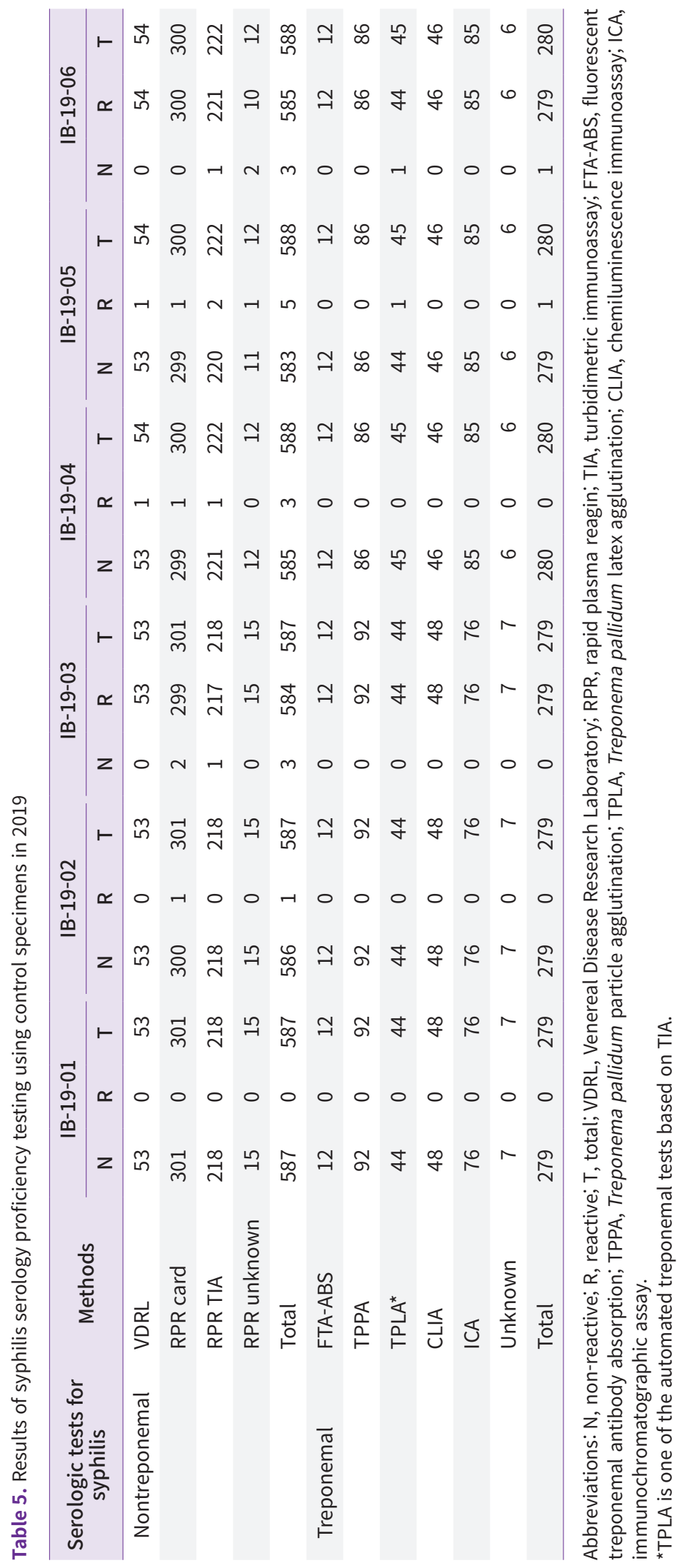




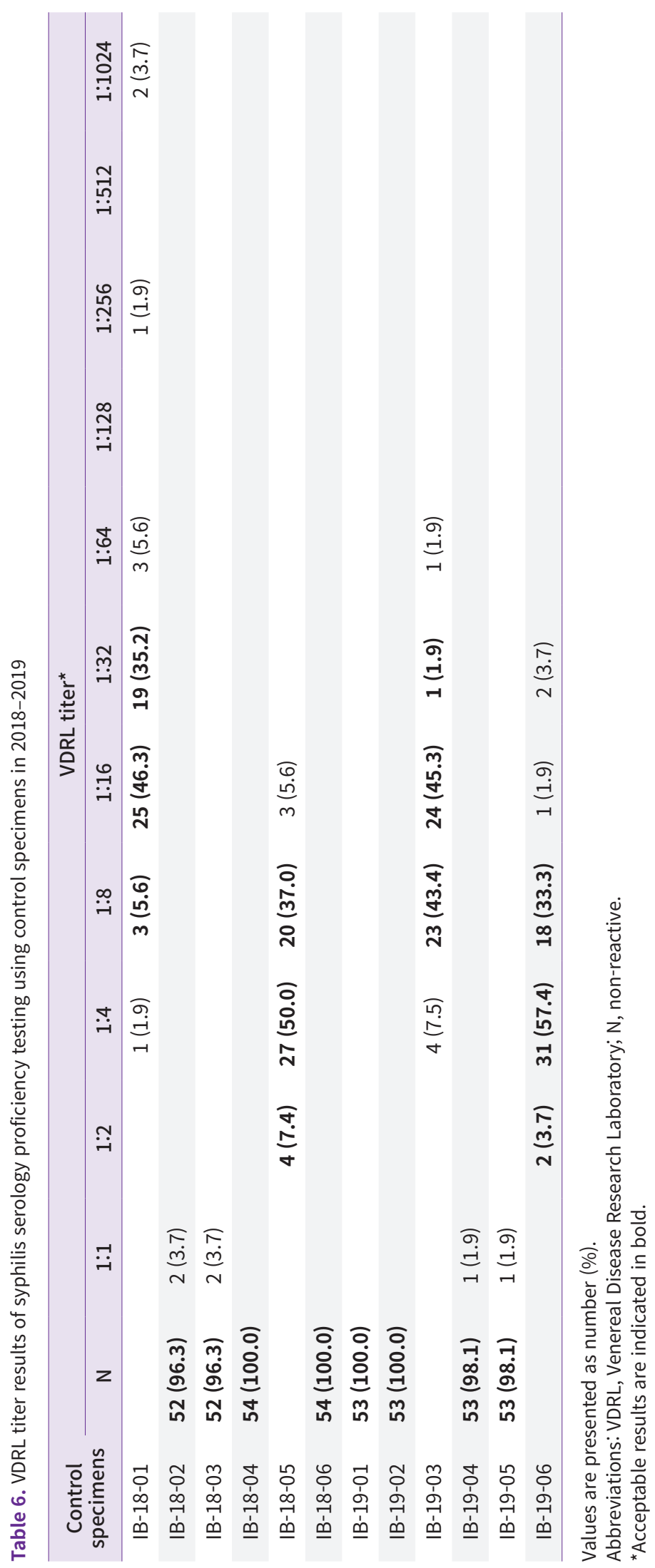


해 'unacceptable'로 판정된 역가를 제시한 기관의 빈도는 각각 $13.0 \%, 5.6 \%, 9.4 \%, 5.6 \%$ 였다. 음성 검체에 대해 양성의 역가를 보고한 경우는 IB-18-02과 IB-18-03에 대해 동일한 2기관(3.7\%), IB-19-04과 IB-19-05에 대해 동일한 1 기관(1.9\%)이 1:1의 낮은 역가로 보고하였다(Table 6).

\section{2) 트레포네마검사}

2018년 1차와 2차 신빙도조사사업의 각 검체당 회신한 모든 트 레포네마검사 결과의 총합을 기준으로 하여 분석하였다. IB-1801 검체에 대한 트레포네마검사 총 277예 중 277예가 양성, IB18-02 검체는 총 277예 중 277예가 음성, IB- $18-03$ 검체는 총 277 예 중 277 예가 음성으로, 모두 $100.0 \%$ 의 정답률을 보였다. IB-18-04 검체에 대한 트레포네마검사 총 277예 중 277예가 음 성, IB-18-05 검체는 총 277예 중 277예가 양성, IB-18-06 검체는 총 277예 중 276예가 음성으로, 각각 $100.0 \%, 100.0 \%, 99.6 \%$ 의 정답률을 보였다(Table 4). 2019년 1차와 2차 신빙도조사사 업의 각 검체당 회신한 모든 트레포네마검사 결과의 총합을 기 준으로 하여 분석하였다. IB-19-01 검체에 대한 트레포네마검사 총 279예 중 279예가 음성, IB-19-02 검체는 총 279예 중 279예 가 음성, IB-19-03 검체는 총 279예 중 279예가 양성으로, 모두 $100.0 \%$ 의 정답률을 보였다. IB-19-04 검체에 대한 트레포네마검 사 총 280예 중 280예가 음성, IB-19-05 검체는 총 280예 중 279 예가 음성, IB-19-06 검체는 총 280예 중 279예가 양성으로, 각각 $100.0 \%, 99.6 \%, 99.6 \%$ 의 정답률을 보였다(Table 5).

\section{고찰}

2018년 감염성 세균항원항체검사 1차와 2차 신빙도조사사업 에 각각 586기관과 589기관이 참여하였고, 2019년 1차와 2차 사 업에 592기관과 587기관이 참여하였다. 새롭게 시작된 2016년 같은 회차에 비해 2019년에는 각각 162 기관(37.7\%)과 155기관 (35.9\%)이 증가하였으며, 해를 거듭할수록 참여도가 증가하는 추 세를 보였다[1]. 2018년 1차 사업의 비트레포네마검사와 트레포 네마검사의 결과 회신율은 각각 $89.6 \%$ 와 $43.9 \%$ 였고, 2 차 사업의 회신율은 각각 $89.3 \%$ 와 $43.5 \%$ 였다. 2019년 1차 사업의 회신율 은 각각 $90.7 \%$ 과 $43.2 \%$ 였고, 2 차 사업의 회신율은 각각 $91.5 \%$ 과 43.8\%로 사업 간 회신율은 통계적으로 유의한 차이는 없었다 (chi-square test, $P>0.05$ ).

2018-2019년 감염성 세균항원항체검사 중 비트레포네마검사 로 RPR card 수기법을 사용하고 있는 기관이 약 $50 \%$ 정도로 가 장 많았으며, 2016-2017년 사용률과 비슷하게 유지되고 있었 다(chi-square test, $P>0.05$ ). RPR TIA 자동화법을 사용하는 기
관의 비율은 2017년 2차 사업의 $36.1 \%$ 에서 2019년 2차 사업 의 $37.8 \%$ 로 비슷한 수준이었다(chi-square test, $P>0.05$ ). 한 편, 2018-2019년 감염성 세균항원항체검사 중 트레포네마검사 는 TPPA를 사용하고 있는 기관의 비율은 2016년 1차 43.9\%에 서 2019년 2차 사업의 $30.7 \%$ 까지 점진적으로 유의하게 감소하 였다(chi-square test, $P<0.01$ ). 이에 반해 ICA를 사용하는 기관 은 2016년 1차 사업의 $13.8 \%$ 에서 2019년 2차 사업의 $30.4 \%$ 까 지 꾸준히 유의하게 증가하였고(chi-square test, $P<0.01$ ) [1], 이 러한 추세는 2014년 이전부터 꾸준히 관찰되고 있었다[2]. 이는 TPPA에 비해 조작이 더 간편한 ICA에 대한 선호도가 높아졌기 때 문으로 예상된다. 본 보고서에는 ICA가 $100 \%$ 의 정확도를 보여주 었지만, ICA가 TPPA보다 낮은 검출률을 나타낸다는 보고들이 있 으므로 정확한 평가를 위해서는 보다 낮은 역가의 검체를 이용한 정도관리가 필요할 수 있다[2,3]. TPLA와 CLIA의 자동화법을 사 용하는 기관의 비율은 각각 약 $15 \%-17 \%$ 정도로 이전 조사결과 와 큰 차이는 없었다.

2017년 1차 신빙도조사사업의 일부 음성 검체에서 비트레포네 마검사와 트레포네마검사 $92.5 \%-94.0 \%$ 의 다소 낮은 정답률을 보였던 것에 비해 2018-2019 신빙도조사사업에서는 모든 검체 에서 99.0\%-100.0\%의 높은 정답률을 보였다. 2016-2017년 신 빙도조사사업 당시에 시료로 이용된 다수에서 유래한 잔여 검체의 기질효과(matrix effect)가 낮은 정답률의 원인으로 추정되었다 [1,4]. 이에 대한 보완책으로 2018년 1차 사업부터는 대한적십자 사 혈액관리본부에서 소수의 공여자의 혈액백을 제공받아 제작한 시료를 사용하여, 신방도조사에 사용되는 자가제조물질의 품질을 보장하고, 비특이적 응집이나 침전의 가능성을 줄여 검사방법 및 시약 간의 일치도를 높일 수 있었다.

\section{감사의 글}

정도관리물질 제조를 위한 혈액 준비에 도움을 주신 대한적십 자사 혈액관리본부 관계자분들과 신빙도조사사업 시 자료 정리에 도움을 주신 신주현, 전지후 선생님께 감사의 말씀을 전한다.

\section{ORCID}

Taeo Ma

Hyun-Woo Choi

Rihwa Choi

Sang-Gon Lee

Seung-Jung Kee https://orcid.org/0000-0002-3972-8766 https://orcid.org/0000-0002-9438-1603 https://orcid.org/0000-0002-8266-2248 https://orcid.org/0000-0002-4672-5811 https://orcid.org/0000-0001-9708-5837 


\section{REFERENCES}

1. Kee SJ, Shin JH, Lee HS, Lee SG. Report on the external quality assessment scheme of serologic tests for syphilis in Korea (2016-2017). J Lab Med Qual Assur 2018;40:182-7.

2. Huh HJ, Chae SL, Oh DJ, Park Q, Lim CS, Um TH, et al. Establishment and multicenter evaluation of a national reference panel for syphilis antibodies in Korea. Lab Med Online 2014;4:36-42.

3. Yi J, Choi W, Shin S, Choi J, Kim H, Chung HJ, et al. Strategy for performing treponemal tests in reverse-sequence algorithms of syphilis diagnosis. Clin Biochem 2019;63:121-5.

4. Rej R. Proficiency testing, matrix effects, and method evaluation. Clin Chem 1994;40:345-6. 